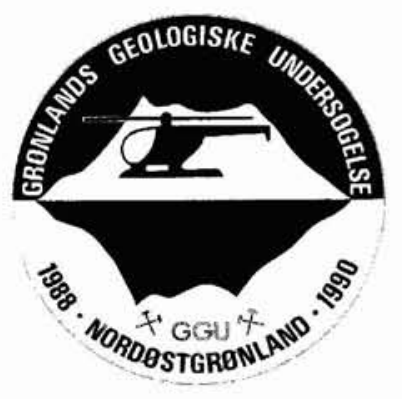

\title{
Reconnaissance for mineral occurrences in North-East Greenland $\left(76^{\circ}-78^{\circ} \mathrm{N}\right)$
}

\author{
Sven Monrad Jensen and Henrik Stendal
}

\begin{abstract}
Reconnaissance for indications of potentially economic mineralisation in the Caledonian fold belt of North-East Greenland has shown that stream sediment geochemical anomalies and mineral occurrences are related to Lower-Middle Proterozoic and Caledonian skarns, Caledonian shear and thrust zones, and breccias in post-Jurassic normal faults. None of the mineral showings are of economic significance. Mineralised rock samples, stream sediment silt samples and panned stream sediment heavy mineral concentrates generally have low contents of metals and incompatible elements, and only few areas stand out as being geochemically anomalous. On the basis of the present knowledge of the geology of the region the mineral potential is considered low.
\end{abstract}

S. M. J., Department of Geology, University of Aarhus, DK-8000 Århus C, Denmark. Present address: Geological Survey of Greenland, Øster Voldgade 10, DK-1350 Copenhagen $K$, Denmark.

H. S., Geological Institute, University of Copenhagen, Øster Voldgade 10, DK-1350 Copenhagen K, Denmark.

Reconnaissance prospecting for indications of mineralisation was carried out in 1990 with the aim of evaluating the mineral potential in the Caledonian fold belt between latitudes $76^{\circ}-78^{\circ} \mathrm{N}$. The areas of investigation give a fair geographical coverage of the main litho-structural units in an east-west section of the fold belt, and include known mineral showings (rust zones and skarns) and geochemical anomalies outlined in GGU's regional reconnaissance geochemical mapping programme (Henriksen, 1990, 1991). Mineralised rock samples, panned heavy mineral concentrates and stream sediment samples were collected in 1990. In addition, sulphide and oxide samples from mineralised localities were collected for lead isotope analysis (Jensen, 1993, 1994). The mineral showings and geochemical characteristics briefly described in this paper have been grouped by genetic type and apparent age of mineralisation: (1) Lower-Middle Proterozoic skarns; (2) mineralisation related to Caledonian thrust and shear zones, and Caledonian skarns; and (3) pyrite-mineralised post-Jurassic fault breccias.

\section{Mineralisation \\ Pre-Caledonian skarns}

Supracrustal rock units are common within the crystalline terrain of the Dove Bugt region and they are often strongly modified along their contacts with orthogneisses (Chadwick et al., 1990). Mineralised skarns in Lower to Middle Proterozoic gneisses have been found in Rech- nitzer Land and on two small islands in Dove Bugt (Fig. 1; Jensen \& Stendal, 1990).

In Ravnedalen in Rechnitzer Land skarn is associated with a thick ( $>500 \mathrm{~m}$ ), broadly conformable sheet of pink hornblende-biotite orthogneiss emplaced into grey gneisses with supracrustal bands. The original contact between pink orthogneiss and supracrustal rocks has been obliterated by high-strain deformation and no coherent contact skarn zone is exposed; instead, small inclusions (1-100 $\mathrm{m}^{2}$ in size) of skarn 'float' in the orthogneisses. The inclusions consist of quartz, hornblende, scapolite, calcite, garnet, diopside and sphene and contain up to $2 \%$ sulphides (pyrite, pyrrhotite and chalcopyrite). The pink orthogneiss is often enriched in magnetite, pyrite and allanite near the skarn inclusions, and radioactivity is often enhanced (scintillometer readings are up to 10 times higher than the background). At one locality, molybdenite was observed in the orthogneiss.

On the eastern side of two small unnamed islands in Dove Bugt a NE-SW trending contact skarn zone between banded paragneisses and pink granitic orthogneiss is exposed over a distance of $c .5 \mathrm{~km}$. The orthogneiss has a sharp, tectonic boundary (which dips $70-80^{\circ} \mathrm{E}$ ) against an up to $10 \mathrm{~m}$ wide skarn zone that consists of strongly deformed, alternating lenses of orthogneiss, marble and garnet, hornblende and magnetite skarns. High levels of radioactivity have been detected in highly deformed domains in the skarn zone and in lenses of massive magnetite. Pyrite occurs in all types of skarn and constitutes 


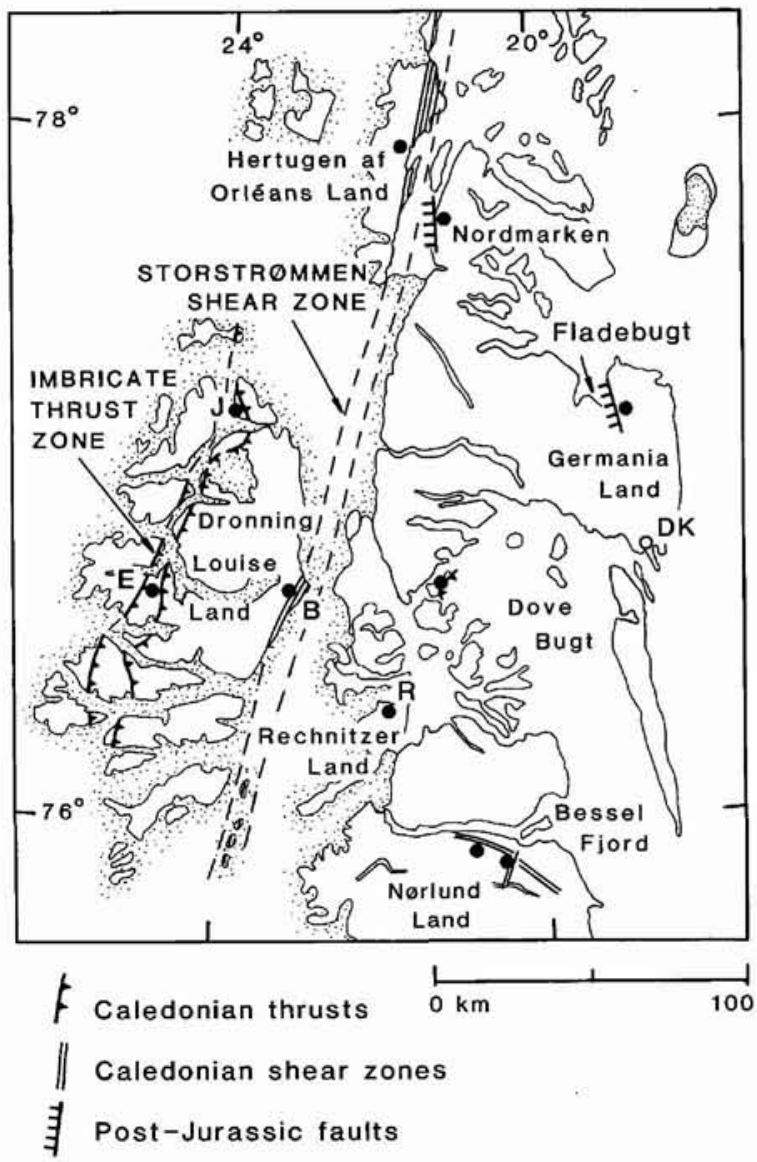

Fig. 1. Map of North-East Greenland $\left(76^{\circ}-78^{\circ} \mathrm{N}\right)$ showing investigated areas (filled circles). $\mathrm{R}=$ Ravnedalen; $\mathrm{B}=$ Borgiøkel; $\mathrm{E}=$ Eigil $\mathrm{S} \emptyset ; \mathrm{J}=\mathrm{H}$. A. Jensen Bjerg; DK = Danmarkshavn.

$0.1-1 \%$ of the rocks. Musgravite, a rare beryllium-bearing oxide mineral, was discovered in white calc-silicate skarn in 1989 (Chadwick et al., 1990, 1993). Idioblastic grains of musgravite $(0.5-3 \mathrm{~mm})$ constitute less than $1 \%$ of thin lenses of marble ( $10 \mathrm{~cm}$ thick and up to $1 \mathrm{~m}$ long) and occur with norbergite (a yellow-brown humite group mineral), phlogopite, blue apatite, fluorite and arsenopyrite in a calcite matrix. The skarn probably formed in the Lower-Middle Proterozoic when the pink granite body intruded the supracrustal rocks, and was deformed and modified by uraniferous metamorphic solutions probably during the Caledonian orogeny.

\section{Caledonian skarn, thrust and shear zones}

Bessel Fjord shear zone and skarn. The Bessel Fjord shear zone in the northern part of Nørlund Land (Fig. 1) strikes E-W to ESE-WNW and separates supracrustal rocks of the Middle Proterozoic Smallefjord sequence to the south from older basement gneisses to the north (Henriksen et al., 1989). Near the mouth of Bessel Fjord the shear zone is displaced by a younger, NNE-SSW trending shear zone (dextral shear sense). The dominant rocks in the area are grey banded gneisses with amphibolites, calc-silicate bands and quartz-feldspar pegmatites. Apart from elevated radioactivity associated with some pegmatites in the sheared and mylonitised rocks, the only signs of element mobilisation in the shear zones are a few occurrences of disseminated pyrite in quartz-garnet-rich gneiss lenses. About 5-10 km south of Bessel Fjord, in the trace of the younger shear zone, the gneisses are much less mylonitised and there are many discordant lenses of relatively fresh amphibolite. The amphibolites contain a little disseminated pyrite (max. $0.5 \%$ ), and pegmatites cutting them often carry magnetite and up to about $1 \%$ pyrite. In contrast, older, conformable amphibolites in the gneisses are partly replaced by biotite and rarely contain sulphides. In a valley about $5 \mathrm{~km}$ to the south of the shear zone, scattered outcrops of marble and quartzite are in contact with underlying Caledonian(?) granite over a large area $\left(\sim 15 \mathrm{~km}^{2}\right)$. At the contacts between supracrustal rocks and granite up to $5 \mathrm{~m}$ wide diopside skarn zones, with or without small amounts of pyrite and pyrrhotite, are developed.

Storstrommen shear zone. The Dronning Louise Land nunatak region is separated from the coastal ice-free areas by the Storstrømmen shear zone, most of which is icecovered. Parts of the shear zone are exposed in the Borgjøkel area of eastern Dronning Louise Land and in Hertugen af Orléans Land (Fig. 1; Strachan et al., 1991). In the Borgjøkel area grey banded gneisses with pods of rusty weathering amphibolite predominate. The amphibolite pods often contain numerous irregular quartz veins with a little pyrite and are rimmed by thin $(5-10 \mathrm{~cm})$ bands of quartz-garnet-rich skarn rock with up to $1 \%$ disseminated pyrite. Similar relationships between amphibolite and gneiss are observed in Hertugen af Orléans Land. Late joints and fractures in the gneisses sometimes contain 1-10 cm wide quartz-calcite veins with a little pyrite, pyrrhotite or in one case, molybdenite.

The imbricate thrust zone of Dronning Louise Land. The $1-5 \mathrm{~km}$ wide Caledonian imbricate zone is comprised of several east-dipping $\left(15-20^{\circ}\right)$ thrust sheets that consist of gneisses, amphibolites and deformed supracrustal rocks (Friderichsen et al., 1990). The metasediments in the imbricate zone are mainly quartzites with subordinate calc-silicate and pelite layers. Hematite- and magnetiterich layers (palaeo-placers) occur in the lower parts of the quartzitic successions. In the Eigil $S \emptyset$ area of western Dronning Louise Land iron oxide-rich layers are rela- 
tively scarce and thin $(1-10 \mathrm{~cm})$ and consist of quartz clasts in a matrix of hematite and minor magnetite. In the H. A. Jensen Bjerg area of northern Dronning Louise Land thick (up to $1 \mathrm{~m}$ ), massive layers with magnetite and hematite in the matrix occur in the quartzites. The thrust sheets are cut by several pegmatites that in the $\mathrm{H}$. A. Jensen Bjerg area form prominent $\mathrm{N}-\mathrm{S}$ striking lineaments and consist of quartz-feldspar-mica ( \pm epidote) assemblages with up to $10 \%$ magnetite and traces of pyrite. The pegmatites are less prominent in the Eigil $\mathbf{\emptyset}$ area and consist almost exclusively of quartz, feldspar and mica. Pyrite mineralisation in the H. A. Jensen Bjerg area (disseminated in a $5 \mathrm{~m}$ thick marble and in an up to $20 \mathrm{~m}$ thick rust zone on the boundary between metasediments and gneisses, and quartz-pyrite-(chalcopyrite) veinlets in gneisses and sandstones) is possibly related to the intrusion of the large pegmatitic bodies.

\section{Post-Jurassic fault breccias}

Prominent rust zones extending over 1-2 km are found in Nordmarken and south-east of Fladebugt (Germania Land; Fig. 1). The rust zones mark late, vertical, N-S striking pyrite-mineralised fault breccias that separate down-faulted blocks of Palaeozoic and Mesozoic sediments from the adjacent Precambrian gneisses.

At the south-eastern corner of Fladebugt a fault breccia zone forms a steep, $75 \mathrm{~m}$ high escarpment. The country rocks to the east are grey gneisses and amphibolites cut by a pegmatite swarm. To the west the down-faulted block is now covered by the sea in Fladebugt. With a total exposed length of about $700 \mathrm{~m}$, the main breccia zone consists of three segments, each about $10 \mathrm{~m}$ wide and a few hundred metres long. In the southern part of the area, two smaller breccia zones (up to $100 \mathrm{~m}$ long and $5 \mathrm{~m}$ wide) parallel the main zone. The pegmatites in the gneisses consist of red $\mathrm{K}$-feldspar, quartz, mica and up to $5 \%$ magnetite. Where faulted and brecciated, the gneiss and pegmatite fragments are silicified and pyritised and set in a matrix of cherty, microcrystalline quartz and pyrite. Late calcite veins (up to $0.5 \mathrm{~m}$ wide) with minor pyrite, fluorite and baryte cut the smaller breccia zones. Most of the iron in the pyrite may have been mobilised from the magnetite-rich pegmatites, so that only sulphur need have been introduced into the fault zone. In the mineralised zones relic crude oil seeps from late joints and tiny pores in the silicified breccia cement. The oil appears to have migrated along the fault planes from buried oil accumulations or oil-producing rocks (Christiansen et al., 1991).

In Nordmarken a $2 \mathrm{~km}$ long fault separates grey gneisses with amphibolites to the east from down-faulted Jurassic sandstones with conglomerates and fossil plant material to the west. The fault zone strikes NNE-SSW $\left(\sim 020^{\circ} \mathrm{E}\right)$ and dips steeply westwards. Both the gneisses and the sandstones along the fault are brecciated in a zone that is generally about $5 \mathrm{~m}$ wide, reaching $30 \mathrm{~m}$ in the middle section. Here, the central part of the breccia is occupied by a massive, $10 \mathrm{~m}$ wide calcite vein with lumps and veinlets of pyrite. In marginal parts of the breccia zone pyrite occurs disseminated and in thin veinlets, constituting up to $5 \%$ of the silicified rocks. Pyrite is also found with coal fragments in the sandstones. Rhodochrosite and black manganese oxide staining are common in all the brecciated rocks.

\section{Geochemical results}

Rock samples $(n=111)$ and stream sediment silt samples $(n=47)$ were analysed for 'Au+34 elements' and panned stream sediment heavy mineral concentrates $(n=22)$ for ' $\mathrm{Au}+33$ elements' by instrumental neutron activation analysis (INAA) at Activation Laboratories Ltd., Ancaster, Ontario. Concentrations of $\mathrm{Cu}, \mathrm{Pb}$ and $\mathrm{Zn}$ in rock samples were analysed by atomic absorption spectrometry (AAS) at the Geological Institute, University of Copenhagen. Summary statistics for the analytical data are given in Tables $1 \& 2$. In the text, abbreviated statistics for sub-ranges of analytical data are presented in the form: element (median / arithmetic mean, number of samples), for example $\mathrm{Zn}$ (626/615 ppm, 12).

\section{Pre-Caledonian skarns}

Streams in Ravnedalen in Rechnitzer Land drain areas of banded gneisses, supracrustal rocks and granitic biotite-amphibole orthogneisses. Stream sediment silt samples show some enrichment in incompatible (including rare earth) elements and in Th $(24 / 23 \mathrm{ppm}, 4)$ and $\mathrm{U}$ $(6.9 / 6.7 \mathrm{ppm}, 4)$. Three corresponding heavy mineral concentrates contain $15-25 \mathrm{ppm}$ U. Rock samples from skarn inclusions in the orthogneisses are slightly enriched in Th (31/34 ppm, 8) and $\mathrm{U}(6.5 / 35 \mathrm{ppm}, 8)$.

Rock samples from skarn on the islands in Dove Bugt generally show high values for As (10/406 ppm, 10), Zn (626/615 ppm, 12), Th (15/78 ppm, 12), U (19/48 ppm, 12) and rare earth elements. A musgravite-rich sample (GGU 365156) contains 3900 ppm As, 650 ppm Zn, 230 ppm W and $47 \mathrm{ppm} \mathrm{U}$, and a comparable sample from the same area collected in 1989 by A. K. Higgins (GGU 339316) contains $5870 \mathrm{ppm} \mathrm{As,} 820 \mathrm{ppm} \mathrm{Zn,} 329 \mathrm{ppm}$ $\mathrm{W}, 79.5 \mathrm{ppm} \mathrm{U}$ and $76.5 \mathrm{ppm}$ Be. Radioactive domains in the skarns (detected by scintillometer readings) are associated with secondary shear planes and fractures in the skarn zones. 
Table 1. Summary statistics for analyses of rock samples and stream sediment silt samples

\begin{tabular}{|c|c|c|c|c|c|c|c|c|c|c|c|c|c|c|}
\hline & \multicolumn{8}{|c|}{ Rock samples } & \multicolumn{5}{|c|}{ Stream sediment samples, silt fraction } \\
\hline & & d.1. & $\mathrm{n}$ & $\min$. & $\max$ & std. & avg. & med. & $\mathrm{n}$ & $\min$. & $\max$. & std. & avg. & med. \\
\hline $\mathrm{Au}$ & $\mathrm{ppb}$ & 5 & 24 & 5 & 195 & 43 & 19 & 6 & 9 & 5 & 105 & 31 & 19 & 8 \\
\hline As & ppm & 2 & 40 & 2 & 3900 & 607 & 115 & 4 & 10 & 2 & 9 & 2 & 3 & 3 \\
\hline $\mathrm{Ba}$ & ppm & 100 & 80 & 100 & 2800 & 466 & 519 & 390 & 46 & 210 & 1200 & 247 & 523 & 475 \\
\hline $\mathrm{Br}$ & ppm & 1 & 5 & 2 & 5 & 1 & 4 & 5 & 32 & 1 & 26 & 5 & 5 & 4 \\
\hline $\mathrm{Ca}$ & $\%$ & 1 & 59 & 1 & 39 & 9 & 10 & 7 & 34 & 1 & 8 & 1 & 3 & 3 \\
\hline Co & ppm & 5 & 53 & 5 & 520 & 73 & 30 & 12 & 46 & 7 & 43 & 9 & 19 & 17 \\
\hline $\mathrm{Cr}$ & ppm & 10 & 109 & 11 & 280 & 45 & 78 & 70 & 46 & 32 & 270 & 56 & 102 & 84 \\
\hline Cs & ppm & 2 & 25 & 2 & 10 & 2 & 4 & 3 & 19 & 2 & 7 & 1 & 4 & 3 \\
\hline $\mathrm{Fe}$ & $\%$ & 0.02 & 111 & 0.23 & 34.2 & 7.09 & 6.17 & 3.95 & 46 & 1.63 & 12.2 & 1.80 & 3.95 & 4.07 \\
\hline Hf & ppm & 1 & 80 & 1 & 39 & 8 & 6 & 3 & 46 & 5 & 110 & 19 & 17 & 11 \\
\hline Mo & ppm & 5 & 27 & 6 & 160 & 31 & 22 & 11 & 0 & & & & & \\
\hline $\mathrm{Na}$ & ppm & 500 & 89 & 505 & 34800 & 9510 & 12895 & 12100 & 46 & 3610 & 20700 & 4810 & 11820 & 12100 \\
\hline $\mathrm{Ni}$ & ppm & 50 & 6 & 50 & 180 & 45 & 100 & 93 & 5 & 76 & 180 & 34 & 127 & 120 \\
\hline $\mathrm{Rb}$ & $\mathrm{ppm}$ & 30 & 73 & 30 & 900 & 127 & 118 & 78 & 42 & 30 & 180 & 41 & 91 & 91.5 \\
\hline $\mathrm{Sb}$ & ppm & 0.2 & 19 & 0.2 & 4.1 & 1.0 & 0.6 & 0.3 & 13 & 0.2 & 0.4 & 0.1 & 0.3 & 0.3 \\
\hline $\mathrm{Sc}$ & ppm & 0.1 & 110 & 0.2 & 56 & 12 & 8.6 & 4.5 & 46 & 8.4 & 53 & 7 & 17 & 17 \\
\hline $\mathrm{Se}$ & $\mathrm{ppm}$ & 5 & 1 & 15 & 15 & 0 & 15 & 15 & 0 & & & & & \\
\hline $\mathrm{Sr}$ & $\%$ & 0.05 & 4 & 0.05 & 0.09 & 0.02 & 0.07 & 0.06 & 2 & 0.07 & 0.07 & 0 & 0.07 & 0.07 \\
\hline $\mathrm{Ta}$ & ppm & 1 & 22 & 1 & 10 & 3 & 3 & 2 & 7 & 1 & 6 & 2 & 2 & 2 \\
\hline Th & $\mathrm{ppm}$ & 0.5 & 90 & 0.5 & 400 & 51 & 22 & 6.5 & 46 & 3 & 110 & 17 & 16 & 12 \\
\hline $\mathrm{U}$ & ppm & 0.5 & 78 & 0.5 & 300 & 40 & 14 & 3.1 & 46 & 1.0 & 17 & 3.0 & 3.8 & 2.8 \\
\hline W & ppm & 4 & 25 & 4 & 2000 & 391 & 97 & 6 & 1 & 7 & 7 & 0 & 7 & 7 \\
\hline $\mathrm{Zn}$ & $\mathrm{ppm}$ & 50 & 37 & 54 & 1380 & 357 & 307 & 110 & 23 & 51 & 180 & 33 & 109 & 110 \\
\hline $\mathrm{La}$ & ppm & 1 & 105 & 1 & 810 & 137 & 69 & 22 & 46 & 15 & 420 & 80 & 87 & 70 \\
\hline $\mathrm{Ce}$ & ppm & 3 & 102 & 3 & 1500 & 215 & 117 & 45 & 46 & 30 & 700 & 132 & 147 & 115 \\
\hline $\mathrm{Nd}$ & ppm & 5 & 80 & 5 & 200 & 46 & 40 & 23 & 46 & 11 & 320 & 61 & 64 & 52 \\
\hline $\mathrm{Sm}$ & ppm & 0.1 & 105 & 0.1 & 36 & 7.1 & 5.3 & 2.8 & 46 & 2.4 & 50 & 10 & 11 & 8.5 \\
\hline $\mathrm{Eu}$ & ppm & 0.2 & 85 & 0.2 & 8.3 & 1.7 & 1.4 & 0.8 & 46 & 0.6 & 7.3 & 1.4 & 1.9 & 1.6 \\
\hline $\mathrm{Tb}$ & ppm & 0.5 & 27 & 0.5 & 6.8 & 1.9 & 2.2 & 1.1 & 29 & 0.5 & 6.8 & 1.3 & 1.9 & 1.5 \\
\hline $\mathrm{Yb}$ & ppm & 0.05 & 105 & 0.07 & 28.0 & 4.58 & 3.16 & 1.48 & 46 & 1.48 & 23.1 & 3.42 & 4.30 & 3.98 \\
\hline $\mathrm{Lu}$ & $\mathrm{ppm}$ & 0.05 & 93 & 0.05 & 5.26 & 0.87 & 0.61 & 0.34 & 46 & 0.23 & 3.92 & 0.57 & 0.65 & 0.60 \\
\hline $\mathrm{Cu}^{*}$ & $\mathrm{ppm}$ & 0.4 & 111 & 1 & 1040 & 119 & 37 & 7 & & & & & & \\
\hline $\mathrm{Pb}^{*}$ & $\mathrm{ppm}$ & 1.0 & 63 & 1 & 202.2 & 29 & 13 & 5.4 & & & & & & \\
\hline $\mathrm{Zn}^{*}$ & ppm & 0.4 & 111 & 0.8 & 862 & 151 & 61 & 18 & & & & & & \\
\hline
\end{tabular}

d.l.: detection limit; $\mathrm{n}$ : number of samples above detection limit; std.: standard deviation; avg.: arithmetic mean; med.: median.

*Atomic absorption spectrometry (AAS) analysis. All other samples: instrumental neutron activation analysis (INAA). The INAA package includes $\mathrm{Ag}, \mathrm{Hg}$, Ir and $\mathrm{Sn}$ but the detection limits of $5 \mathrm{ppm}, 1 \mathrm{ppm}, 5 \mathrm{ppb}$ and $0.01 \%$, respectively, were not exceeded in any sample.

\section{Caledonian skarn, thrust and shear zones}

Bessel Fjord shear zone and skarn. Stream sediment samples from the northern part of Nørlund Land are clearly anomalous with respect to lithofile (including rare earth) and siderofile elements (especially $\mathrm{Ba}, \mathrm{Ce}, \mathrm{Cs}$, $\mathrm{La}$, $\mathrm{Rb}, \mathrm{Sm}, \mathrm{Sr}, \mathrm{Zr}, \mathrm{Y}$, and $\mathrm{Cr}, \mathrm{Fe}, \mathrm{Ni}$, and $\mathrm{V}$ ) compared to data for neighbouring areas. The geochemical anomalies can be attributed to the presence of pegmatites in the gneisses and occurrences of diopside-dominated skarn at the contacts between Caledonian(?) granites and metasediments of the Middle Proterozoic Smallefjord sequence. Enhanced values for elements such as $\mathrm{Cr}, \mathrm{Ni}$ and $\mathrm{V}$ are probably caused by amphibolitic rocks in the gneisses. Panned heavy mineral samples generally confirm the anomaly patterns from stream sediment silt samples, most clearly so for Th, $\mathrm{U}$ and rare earth elements. Rock samples of sheared and mylonitised gneisses from the Bessel Fjord shear zone show scattered high contents of various elements; a mylonitised sample contains 2000 ppm W but is otherwise unremarkable, and an amphibolite sample has elevated values of $\mathrm{Ba}(1200 \mathrm{ppm})$, Th (46 ppm) and rare earth elements. A stream sediment sample collected here has the highest content of rare earth elements, Ta $(6 \mathrm{ppm})$, Th $(110 \mathrm{ppm})$ and $\mathrm{U}(17 \mathrm{ppm})$ of all 47 silt samples.

Storstrommen shear zone. Stream sediment silt samples 
collected in 1989 (see Henriksen, 1990) showed two small gold anomalies ( 24 and $59 \mathrm{ppb}$ ) and slight enrichment in $\mathrm{Ba}, \mathrm{Sr}$ and $\mathrm{Ce}$ near the Storstrømmen shear zone in eastern Dronning Louise Land. Further sampling in the same area in 1990 resulted in scattered anomalous gold values; a heavy mineral sample contains $72 \mathrm{ppb} A u$ and a stream sediment silt sample $105 \mathrm{ppb}$ Au. Slightly elevated values for $\mathrm{Th}(10-19 \mathrm{ppm})$ and $\mathrm{Cu}(53-100 \mathrm{ppm})$ in rock samples are restricted to mylonitised amphibolites and skarnoid quartz-garnet-rich alteration rims on amphibolite pods. None of the analysed pyrite-bearing rock samples contain detectable amounts of gold, and the sources of the small gold anomalies in stream sediment silt and heavy mineral samples thus remain unknown.

In Hertugen af Orléans Land, in the northern continuation of the Storstrømmen shear zone, very little field or geochemical evidence of mineralisation has been found. $\mathrm{Zn}$ is marginally higher in two of three panned heavy

Table 2. Summary statistics for analyses of panned heavy mineral samples

\begin{tabular}{|c|c|c|c|c|c|c|c|c|}
\hline & & d.I. & $\mathrm{n}$ & $\min$. & $\max$ & std. & avg. & med. \\
\hline $\mathrm{Au}$ & $\mathrm{ppb}$ & 5 & 5 & 6 & 72 & 25 & 22 & 11 \\
\hline As & ppm & 2 & 7 & 2 & 6 & 1 & 4 & 4 \\
\hline $\mathrm{Ba}$ & ppm & 200 & 3 & 550 & 630 & 33 & 587 & 580 \\
\hline $\mathrm{Ca}$ & $\%$ & 1 & 14 & 4 & 11 & 2 & 6 & 7 \\
\hline $\mathrm{Co}$ & $\mathrm{ppm}$ & 5 & 22 & 14 & 79 & 12 & 31 & 29 \\
\hline $\mathrm{Cr}$ & $\mathrm{ppm}$ & 10 & 22 & 40 & 350 & 87 & 188 & 185 \\
\hline $\mathrm{Cs}$ & ppm & 2 & 3 & 2 & 5 & 1 & 3 & 3 \\
\hline $\mathrm{Fe}$ & $\%$ & 0.02 & 22 & 7.55 & 41.0 & 6.83 & 15.9 & 14.8 \\
\hline Hf & ppm & 1 & 22 & 6 & 220 & 60 & 54 & 31 \\
\hline $\mathrm{Na}$ & ppm & 500 & 22 & 1900 & 33880 & 8300 & 9670 & 6860 \\
\hline $\mathrm{Ni}$ & ppm & 200 & 4 & 200 & 290 & 41 & 240 & 235 \\
\hline $\mathrm{Rb}$ & ppm & 50 & 1 & 64 & 64 & 0 & 64 & 64 \\
\hline $\mathrm{Sb}$ & $\mathrm{ppm}$ & 0.2 & 4 & 0.4 & 1.2 & 0.3 & 0.7 & 0.6 \\
\hline $\mathrm{Sc}$ & ppm & 0.1 & 22 & 12 & 110 & 28 & 60 & 55 \\
\hline $\mathrm{Ta}$ & ppm & 1 & 22 & 2 & 10 & 2 & 3 & 3 \\
\hline Th & ppm & 0.5 & 22 & 3.9 & 130 & 34 & 40 & 30 \\
\hline $\mathrm{U}$ & ppm & 0.5 & 22 & 0.7 & 25 & 6.9 & 9.3 & 6.4 \\
\hline W & ppm & 4 & 5 & 7 & 14 & 2 & 10 & 10 \\
\hline $\mathrm{Zn}$ & ppm & 200 & 9 & 200 & 280 & 24 & 230 & 220 \\
\hline $\mathrm{La}$ & $\mathrm{ppm}$ & 1 & 22 & 32 & 750 & 172 & 192 & 145 \\
\hline $\mathrm{Ce}$ & ppm & 3 & 22 & 56 & 880 & 213 & 271 & 210 \\
\hline $\mathrm{Nd}$ & ppm & 10 & 22 & 22 & 330 & 85 & 107 & 82 \\
\hline $\mathrm{Sm}$ & ppm & 0.1 & 22 & 4.9 & 59 & 13 & 19 & 15 \\
\hline $\mathrm{Eu}$ & ppm & 0.2 & 22 & 1.2 & 7.9 & 1.4 & 2.6 & 2.1 \\
\hline $\mathrm{Tb}$ & ppm & 2 & 16 & 2 & 8 & 2 & 5 & 5 \\
\hline $\mathrm{Yb}$ & ppm & 0.2 & 22 & 4.6 & 51.3 & 14.4 & 22.3 & 20.7 \\
\hline $\mathrm{Lu}$ & ppm & 0.1 & 22 & 0.4 & 8.3 & 2.4 & 3.6 & 3.6 \\
\hline
\end{tabular}

See notes to Table I for explanation of abbreviations. All elements analysed by INAA.

The detection limits for $\mathrm{Ag}$ ( $5 \mathrm{ppm}), \mathrm{Br}$ ( $5 \mathrm{ppm}), \mathrm{Hg}$ (5 ppm), $\mathrm{Ir}$ (40 $\mathrm{ppb}), \mathrm{Mo}(20 \mathrm{ppm}), \mathrm{Se}(20 \mathrm{ppm})$ and $\mathrm{Sr}(0.2 \%)$ were not exceeded in any sample.

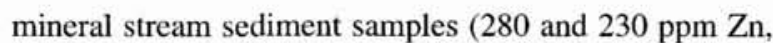
respectively). Two pyrite-bearing gneissic rock samples have relatively high contents of $\mathrm{Ba}(1200$ and $1600 \mathrm{ppm})$, Th (52 and $42 \mathrm{ppm}), \mathrm{U}$ (14 ppm), Zn (226 and 139 ppm) and rare earth elements.

The imbricate thrust zone of Dronning Louise Land. The sampled streams drain areas with quartzites and gneisses within the imbricate zone. A panned heavy mineral sample is anomalously high in Ta (10 ppm), Th $(130 \mathrm{ppm})$, $\mathrm{La}(750 \mathrm{ppm}), \mathrm{Ce}(880 \mathrm{ppm})$ and $\mathrm{Nd}(330 \mathrm{ppm})$. In three stream sediment samples from the Eigil $\mathrm{\wp} \emptyset$ area in western Dronning Louise Land no elements are conspicuously high and only slight enhancement in $\mathrm{La}, \mathrm{Ce}, \mathrm{Nd}$ and $\mathrm{Th}$ is seen. Anomalous contents of U ( $45 \mathrm{ppm}), \mathrm{Th}(55 / 62 \mathrm{ppm}$, 3 ) and rare earth elements are found in rock samples of pegmatites and aplite dykes of probable Caledonian age that have intruded the amphibolites and augen gneisses in the imbricate zone. A large rust zone on $\mathrm{H}$. A. Jensen Bjerg in northern Dronning Louise Land, represented by five rock samples, shows only two anomalous Mo values (23 and $32 \mathrm{ppm}$ ). A magnetite-rich pegmatite sample contains $70 \mathrm{ppm}$ Th.

\section{Post-Jurassic fault breccias}

A small stream crosses the southern end of the N-S striking breccia zone at Fladebugt; a panned heavy mineral sample collected here is one of only five samples collected in 1990 containing detectable Au (12 ppb) and is enhanced in Ba ( $580 \mathrm{ppm})$, $\mathrm{Hf}(220 \mathrm{ppm})$ and $\mathrm{U}(22$ $\mathrm{ppm})$. Analyses of rock samples from the pyrite-mineralised fault breccia show slight enrichment relative to the background only for As (6/10 ppm, 6) and Mo (12/12 ppm, 7).

From the N-S striking fault breccia in Nordmarken a panned heavy mineral concentrate from a stream crossing the southern end of the breccia zone contains $11 \mathrm{ppb} \mathrm{Au}$. Rock samples $(n=19)$ from Nordmarken generally show enrichment in Au (10/58 ppb, 6), As (41/75 ppm, 6) and Mo (30/36 ppm, 5). The highest Au values (195 and 123 $\mathrm{ppb}$ ) in the region are from the central, massive calcitepyrite vein. These two samples also have high contents of As (190 and $160 \mathrm{ppm})$ and Mo (75 and $55 \mathrm{ppm})$.

\section{Conclusions}

Indications of mineralisation in the region studied are few and scattered. With respect to mineral occurrences of potential economic interest (e.g. base metal sulphides and rare earth element-bearing minerals in skarns) the known indications point to insignificant concentrations. Only iron oxides (magnetite and hematite) and pyrite have 
been found to occur in moderate amounts, in Caledonian thrust zones and in late, $\mathrm{N}-\mathrm{S}$ striking fault breccia zones, respectively. Small gold anomalies $(\max .105 \mathrm{ppb})$ have been detected in stream sediments from the Storstrømmen shear zone in eastern Dronning Louise Land and in rock samples from the Nordmarken pyrite-mineralised fault breccia (max. $195 \mathrm{ppb}$ ).

In most cases, observed field relationships of major rock units can adequately explain the stream sediment anomaly patterns. At the contacts between granitic intrusions (now orthogneisses) and their supracrustal host rocks various types of skarn have resulted in elevated contents of elements such as Sc, Th, U, W, La, Ce, Nd, $\mathrm{Tb}, \mathrm{Yb}$ and $\mathrm{Lu}$ in drainage samples. Rock samples from the skarns often have high contents of As, Mo, Zn, U, Th and rare earth elements. In northern Nørlund Land, where granites and pegmatites of possible Caledonian age have intruded the Middle Proterozoic Smallefjord sequence supracrustal rocks, even small outcrops of the intrusives appear to result in pronounced stream sediment anomalies.

The potential for significant occurrences of base and precious metals in the region studied is considered low, in view of the lack of geochemical indications, significant mineral showings, extensive supracrustal sequences, greenstone belts or evidence for pervasive hydrothermal alteration in structurally favourable settings.

\section{References}

Chadwick, B., Friend, C. R. L. \& Higgins, A. K. 1990: The crystalline rocks of western and southern Dove Bugt, NorthEast Greenland. Rapp. Gronlands geol. Unders. 148, 127132.
Chadwick, B., Friend, C. R. L., George, M. C. \& Perkins, W. T. 1993: A new occurrence of musgravite, a rare beryllium oxide, in the Caledonides of North-East Greenland. Mineralog. Mag. 57, 121-129.

Christiansen, F. G., Bojesen-Koefoed, J., Jensen, S. M. \& Stemmerik, L. 1991: Oil seep in basement, Germania Land, NorthEast Greenland. Open File Ser. Gronlands geol. Unders. 91/7, $18 \mathrm{pp}$.

Friderichsen, J. D., Holdsworth, R. E., Jepsen, H. F. \& Strachan, R. A. 1990: Caledonian and pre-Caledonian geology of Dronning Louise Land, North-East Greenland. Rapp. Gronlands geol. Unders. 148, 133-141.

Henriksen, N. 1990: Regional geology and 1:500 000 mapping in North-East Greenland. Rapp. Gronlands geol. Unders. 148, 16-20.

Henriksen, N. 1991: The North-East Greenland project 19881990. Rapp. Gronlands geol. Unders. 152, 24-29.

Henriksen, N., Friderichsen, J. D., Strachan, R. A., Soper, N. J. \& Higgins, A. K. 1989: Caledonian and pre-Caledonian geology of the region between Grandjean Fjord and Bessel Fjord $\left(75^{\circ}-76^{\circ} \mathrm{N}\right)$, North-East Greenland. Rapp. Gronlands geol. Unders. 145, 90-97.

Jensen, S. M. 1993: Lead isotope studies on mineral showings and ore deposits in East Greenland. Rapp. Gronlands geol. Unders. 159, 101-108.

Jensen, S. M. 1994: Lead isotope signatures of mineralised rocks in the Caledonian fold belt of North-East Greenland. Rapp. Gronlands geol. Unders. 162 (this volume).

Jensen, S. M. \& Stendal, H. 1990: Geochemical and ore geological field investigations in North-East Greenland $\left(76^{\circ}-\right.$ $78^{\circ} \mathrm{N}$ ). Express Report North-East Greenland 1990. Unpubl. intern. GGU rep., 49-55.

Strachan, R. A., Jepsen, H. F. \& Kalsbeek, F. 1991: Regional Caledonian structure of Hertugen af Orléans Land, NorthEast Greenland. Rapp. Gronlands geol. Unders. 152, 95-102. 